\title{
Stylistic Metaphor: Senses Of Sight And Smell In The Works of Martin Luther King Junior. And Bate Besong
}

\author{
SEINO Evangeline Agwa Fomukong \\ Higher Teacher Training College (HTTC), The University of Bamenda, \\ P.O. Box 39, Bambili - Bamenda, Cameroon
}

\begin{abstract}
Stylisticians analyse texts looking at how language affects readers. This implies that the writer or the speaker of a text takes into account the choice of language, that is, what will affect the reader or listener in the way the writer or speaker wants. They intent of the writer or speaker may come with images that are trigged off by language through which they recall or evoke instances of physical sensual perception. Martin Luther King Junior and Bate Besong are authors who make use of the sensual perception of darkness and stench, respectively in their works. The study using the Dual Coding Theory and Conceptual Metaphor Theory concludes that racial discrimination is darkness and any social ill is stench.
\end{abstract}

Key words: imagery, metaphor, decadence, stench, darkness.

\section{INTRODUCTION}

Stylisticians analyse texts looking at how language affects readers. This implies that the writer or the speaker of a text takes into account the choice of language, that is, what will affect the reader or listener in the way the writer or speaker wants. They intent of the writer or speaker may come with images that are trigged off by language through which they recall or evoke instances of physical sensual perception. The language could therefore be considered a bridge linking the external world and the human mind. These writers have abstract ideas which become concrete with the use of images. Meanwhile, these images help readers to easily understand what is being communication and can easily retain these ideas. This is because the image which is a sensory perception of an abstract notion, is made up of words, but is a supraverbal entity. It awakens stored perceptions and sensations in the reader's mind. Stephen King in Keleshian (2014) writers that imagery does not occur on the writer's page; it occurs in the writer's mind. To describe everything is to supply a photograph in words that encapsulates the meaning of the writer using imagery to show the reader the story instead of telling them.

Imagery is the use of descriptive language, which appeals to all the sense. It often makes writing more interesting through the use of sensory detail and adds deeper symbolic meaning to the text (Howard study.com/academy/lesson/symbolism-imagery). Imagery also means to use figurative language to represent objects, actions and ideas creating visual representation of ideas in the minds of readers. Imagery therefore needs the figures of speech like smile, metaphor, personification onomatopoeia etc in order to appeal to the bodily sense. One of the figures of speech that uses imagery is the metaphor. A metaphor is a figure of speech in which a word or phrase is applied to an object or action to which it is not literally applicable. That is, it refers to one thing by mentioning another thing. It may provide clarity or identity and hidden similarities between two ideas. Cameron and Maslen (2010, pp. 1) define metaphor as 'seeing one thing in terms of another, a multi-dimensional discourse phenomenon that involves 
language, thinking, physicality and social interaction.' They examine different dimensions of metaphor which are linguistic, embodied, cognitive, affective, socio-cultural, dynamic (pp.3).

Metaphor identifies one conception (the tenor) with another (the Vehicle). The tenor being the idea expressed (the subject of the comparison) and the vehicle being the image by which this idea is conveyed (the subject of communication). Goatly (2010, pp. 178) argues that 'a metaphor occurs when a term is applied unconditionally. And when the unconditional application is understood on the basis of a similarity or analogy. This similarity or analogy involves the conventional application of the term and the actual unconventional application.' He goes on to explain from the definition that the metaphor has a topic or target, a vehicle or source, and ground. Cameron and Maslen (2010, pp.7) posit that the idea of metaphor has a socio-cultural and interpersonal relation and reveals the speaker's emotions, attitudes and values. This brings about an interplay between the direct meaning and a transferred meaning imposed on the word by the context. Using metaphor appropriately, appeals directly to the senses of listeners and readers, helping them to better understand what is being communicated to them, through images, making them examine ideas and view their environments and the world in different ways. For the writer or speaker to use a metaphor, they compare what they are describing to an image that their reader or listeners is already familiar with, bringing the abstract to concrete terms. Llorens describes the expression of abstraction in concrete terms in TS Eliot's use of figuration. Llorens explains that T.S. Eliot used the image of the wasteland 'rich in sensual evocations (aridity, drought, barrenness, heat), to represent abstract notions about the world where he lived which is filled with hopelessness, materalisation, shock, war that had surpassed all previous wars in its destruction.'

Much work has been done in metaphor but this study limits it to what is related to this work. Ambe (2004) discusses Besong's Beasts of No Nation from the smell of shit in the play. Ambe argues that Besong in Beasts of No Nation recasts the reality of Anglophone Cameroon's marginalisation as 'second class citizens' and their leaders as insatiable locusts devouring tonnes of green, yet producing nothing but buckets of shit. Since shit is the main product in the play's setting and its stench looms freely everywhere in the theatre space, shit and stench become the central organising metaphor in the play. He therefore looks at marginalisation as shit and stench and concludes that the symbolism of the night-soil men as carriers of shit buckets, stench and rot, documents the realities of a postcolonial Cameroon society and emphasizes the long history of the Anglophones, who have been losers and victims in the formation and evolution of the Cameroonian nation at colonisation. Nchia (2016) is in line with Ambe but looks at the image of an 'old dance.' Nchia (2016) discusses Besong's plays as 'new people, new style, old dance.' It is an old dance of oppression, exploitation and marginalisation of the colonised people because these became more traumatic in neo-colonisation. Nchia explains that Beasts of No Nation re-awakens the inequalities that exist between the Francophones and the Anglophones and sums up saying Besong wishes for 'new leaders, new style, new dancing which place the interest of the community above individual interest' (2016,pp.90). Fomukong (2013) in her analysis of Beasts of No Nation, focuses on the biblical reference used by Besong to educate the masses on their plight. In this work she brings out Besong's use of the Holy Bible 'Anglos' fight for their rights. In another work Yimbu (2016) analyses the plays of Walcott and Besong. He brings out Besong's references to real concepts as plebiscite, referendum, reunification and integration which are all linked to the political history of Cameroon and are relevant in the Anglophone struggle for equal rights in Cameroon. He concludes that the strength of literary commitment lies in the use of historical, physical and recognizable reference with symbolic meaning. Dlugan (2012) analyses I Have a Dream by Martin Luther King Junior (MLKJ) and brings out stylistic aspects of anaphora, allusion, 
geographical references and the use of metaphor to highlight contrasting concepts. Dlugan states that metaphors allow speech makers to associate their concepts with concrete images and emotions. He brings out King's use of contrasting metaphors, an example of 'dark desolate valley of segregation and sunlit path of racial justice. Fomukong (2015), in line with Dlugan goes further to analyse the use of triads, antithetical structures and biblical allusions in most of MLKJ's speeches. Other works on MLKJ have analysed the distribution of nouns within two basic semantic classes, that is, nouns related to humans and nouns related to nature in Give us the Ballots.

Many works on MLKJ and Bate Besong have dealt with their fight for freedom but have not discussed the consistency of darkness and stench respectively in some of their works. This study delves into the use of images of the sense of sight by MLKJ in his speeches and the sense of smell by Bate Besong in his plays to pass across their messages. This study uses a descriptive approach in analysis the texts.

\section{SOCIOPOLITICAL CONTEXTS}

Martin Luther King Jr (late), a black American, was born on January 15, 1929 at Atlanta, Georgia, USA. As a baptize minister and a civil-rights activist, he stood up against racial discrimination. In his speeches from mid-1950s to 1968 when he was assassinated, he fought for the blacks. He was for nonviolent strikes and even won a Nobel Peace Prize in 1964. He was arrested and locked up in Birmingham prison and while in prison his still continued with his fight for the blacks. His basis was the Declaration which gave blacks freedom and the right to function as Americans. Most of his speeches were encouraging the blacks to fight for their rights, and fight nonviolently.

Bate Besong (late) was an Anglophone Cameroonian from the South West Region of Cameroon. He was a critic, a playwright, a poet, and a lecturer in the University of Buea, South West Region of Cameroon. He was very critical of the Francophone led government and was once locked up in prison. His plays, poems and critical works exposed the Cameroonian society as a decayed society, through prison conditions, handling elections, corruption, embezzlement, marginalisation etc. He stood on the side of the mass and was disappointed when the mass would not fight for their rights. In Beasts of No Nation through Narrator, he scolds at the masses for wasting his time and his years in educating them.

\section{THEORETICAL FRAMEWORK}

This study uses as theoretical framework, the dual coding theory and the conceptual metaphor theory.

\section{The Dual Coding Theory}

The Dual Coding Theory of Allan Paivio states that there are two types of representational units in the human cognitive systems dealing with verbal and nonverbal languages. Sadoski (2002-03) explains that the verbal code is a mental code specialized for dealing with verbal language. The processes deal with what Paivio considers 'logogens' which is the language system peculiar in that it deals directly with the linguistic input and output. Verbal language provides a means for the encoding, and decoding of messages. The nonverbal code in other words 'images' deals with mental images that can be objects, events, behaviours. Sadoski (2002-03) argues that the nonverbal code is represented in multiple sense: sight, sound, smell, taste and touch sensations. Paivio claimed that the picture memory was superior because whenever one sees a picture it is also represented verbally, and seeing a word does not always form a mental image of the word. The Dual Coding Theory has been applied to different 
psychological processes like education, thinking processes, language and understanding, and metaphor. In reading comprehension according to Sadoski, we often do not fully comprehend unless we can generate a mental model of the text. Sadoski (2002-03) argues that T S Eliot (1960) maintained that the only way to express emotion in poetry was to find an 'objective correlative' a set of concrete objects or events that evoked an emotion in the reader without actually stating that emotion. The basic assumption of Dual Coding Theory therefore is that all mental representations retain some of the concrete qualities of the external experiences from which they derive. The linguistic and nonlinguistic codes account for knowledge of language and knowledge of the world.

\section{The Conceptual Metaphor}

A conceptual metaphor is a metaphor (or figurative comparison) in which one idea (or conceptual domain) is understood in terms of another. In this situation, the more abstract concepts are used to better explain the prototype concrete processes. Deignan (2010) explains that the fundamental tenet of conceptual metaphor theory is that metaphor operates at the level of thinking and argue that metaphors link two conceptual 'domains.' The elements comprising a domain are lexicalized, that is, expressed in language, through words and expressions. The two domains are termed the 'source' domain and the 'target' domain. The source domain is usually concrete consisting of entities, attributes, and processes and relationships that are usually physical experiences stored up in the mind, and the literal meanings associated with the ideas is the source domain. The target domain is abstract and takes its structure from the source domain, through the metaphorical link. Words and expressions from the source domain are used to talk about the target domain. Goaty (2010, pp.180) holds that one of the claims of the Conceptual Metaphor Theory would be that abstract thought is only possible through the use of metaphor. According to Goatly, one of the most important insights of conceptual metaphor theory is that these concrete vehicles for abstract topics do not occur randomly but fall into patterns, which we might call Conceptual Metaphor themes or Conceptual Metaphor or Metaphor Themes, for short. These are conventionally referred to by the capitalized formula X IS Y.

The Dual Coding Theory and the Conceptual Metaphor Theory both dwell on the mental images coming from physical experiences. The experience of the senses of sight of darkness and smell of stench are what have been experienced by MLKJ and Besong's audiences. They have it as mental representations that are used by these authors as concrete images for the source domains to make their audience better understand the intentions of the oppressors and the reason they, the audience have to fight for their rights.

This work discusses the following speeches by Martin Luther King Junior: Give us the Ballot, Great March on Detroit, The Quest For Peace And Justice, I Have A Dream, Nobel Peace Prize Acceptance Speech, Beyond Vietnam: A Time to Break the Silence, Where Do We Go From Here and I've been to the Mountain Top. For Bate Besong, the following plays are discussed: Change Waka \& His Man Sawa Boy, Once Upon Great Lepers and Beasts of No Nation. The stylistic aspect focused on is the use of darkness as metaphor for the sense of sight in MLKJ's speeches and the use of stench in Bate Besong's plays as a metaphor for the sense of smell. In this study, the relationships from the source domains of Bate Besong's stench and Martin Luther King Jr's darkness can be turned into metaphorical clean and bright societies respectively. These are shown through the images used by these authors that bring out their ideologies for making their societies better. Besong therefore considers a corrupt society oppression and corruption is decadence and racial discrimination is darkness. The descriptive approach is used for data analyses. The different instances of darkness and stench are sorted out and described. 


\section{Darkness}

\section{RESULTS AND DISCUSSION}

Darkness is a notion that represents the state of being dark or the absence of light. It a sense of sight. Biblically darkness is a symbol of evil or mystery of fear. In literature light and dark imagery can be used to contrast good and bad, love and hate or life and death.

Wilkins (www.biblestudytools.com) states that 'If light symbolizes God, darkness connotes everything that is anti-God: the wicked and death.' He goes on to quote references from the Holy Bible that support darkness as evil. He quotes Isaiah 9:2 where it is written, salvation brings light to those in darkness, 2Peter 2:4, Hell and 'pits of darkness' describe the fate of angels who sin and Rev 21:23-24 gives hope for believers whose darkness will be dispelled by the presence of the light of the glory of God. It is from this point of view that MLKJ looks at darkness and relates darkness to racial discrimination.

\section{Racial Discrimination Is Darkness}

In Give us the Ballot MLKJ refers to the period of black enslavement in America as 'the long night of human captivity.' The description of human captivity is looked at and considered by MLKJ to be best understood through the image of the night. The human captivity is racial segregation on the blacks. 'Night' here represents darkness, a sight known by all listening to MLKJ. He goes on encouraging the blacks to continue fighting for the goal of freedom. He calls on his audience not to be bitter because they have stood amid the 'tragic midnight of oppression.' That is the experience of those who have been trampled over and those who have been kicked about. The inhuman treatment is because they are blacks. MLKJ uses darkness as racial injustice when he says the blacks should resist all oppression like losing jobs, restless nights, suffering and sacrificing so that future historians will say there was a 'people which stood up with dignity and honor and saved Western civilization in her darkest hour...' The darkest hour here represents the time when Western civilization perpetuated racial discrimination.

The Great March on Detroit was a speech by MLKJ at a nonviolent march in Detroit. The blacks in America were protesting against racial discrimination and asking for their freedom to live as free citizens in America. MLKJ uses the sense of sight, through image of darkness to portray the position, situation and condition of the blacks in America at the time.' He uses darkness as pain, shame, sorrow, colour, the absence of light to make the black's plight vivid. In this speech MLKJ advices the blacks and makes them determined by telling them the whites do what they want but the blacks should not retaliate with violence because this method weakens the morale of the opponent and works on his conscience. He calls on the blacks not to resist. He says 'Nobody with any sense likes to go to jail. But if he puts you in jail, you will go in that jail and transform it from a dungeon of shame to a haven of freedom and human dignity.' A dungeon is a dark underground room used as a prison. The prison where the blacks were thrown into might have not been dark, but the darkness comes with the act and the conditions of the blacks. The dungeon is the image of segregation, discrimination, pain and sorrow. The dungeon of shame will become the haven of freedom and human dignity because of the blacks. The course of the blacks is worth dying for. In consoling his followers he says 'I go back to the South not with a feeling that we are caught in a dark dungeon that will never lead to a way out.' And ends his speech with 'with his faith, I will go out with you and transform dark yesterdays into bright tomorrows.' He considers the past to be dark yesterdays. He already forsees freedom and so considers racial discrimination something of the past. 
In his acceptance letter of the Nobel Peace prize, he lectures on The Quest For Peace And Justice. He describes the two realms, the internal and the external, in which every man lives. He explains that the internal is the spiritual expressed in air, literature, morals, and religion and the external is that complex of devices, techniques, mechanisms, and instrumentalities. He tells his audience that the problem of the day is that people have allowed the internal to become lost in the external. He laments that 'when the 'without' of man's nature subjugates the 'within', dark storm clouds begin to form in the world.' The image of 'darkness' here represents evil, the inhuman treatment by other humans, racial injustice, poverty, and war. He considers the rumbling of discontent to come from 'dungeons of oppression.' He explains that the people, the blacks who could not fight are standing up for the rights 'carving a tunnel of hope through the dark mountain of despair' and 'the people who sat in darkness have seen a great light.' The 'dark mountain of despair' represents the obstacle the blacks had not being able to fight and can now fight. He hopes that good may yet reign in the hearts of men in 'a dark world.'

In I Have A Dream MLKJ refers to the period before America signed the Emancipation Proclamation as a 'long night of captivity' and the period after the decree was signed to be a 'joyous daybreak.' The long night of captivity portrays a time of ignorance in which the blacks suffered oppression. He goes on to say 'now is the time to rise from the dark and desolate valley of segregation to the sunlit path of racial justice.' The comparison is that of darkness to segregation and sunlit to racial justice.

In the Nobel Peace Prize Acceptance Speech, he begins by acknowledging the prize at a moment when 2 million negroes of the USA are engaged in a creative battle to end the 'long night of racial injustice.' He accepts the prize but refuses the view that 'mankind is so tragically bound to the starless midnight of racism and war' that the bright daybreak of peace and brotherhood can never become a reality. But are living in faith that can give them courage to face the uncertainties of the future and when their 'nights became darker than a thousand midnights' they will still hope and know that there are better days ahead.

In Beyond Vietnam: A Time to Break the Silence he speaks on the issue of America involvement in the war in Vietnam ' breaking the silence of the night' and as he says they are in need of a new way 'beyond the darkness that seems so close around us.' He says they are "sending men home from dark and bloody battlefields physically handicapped and psychologically deranged.' They are standing up against this old systems of exploitation and oppression because the 'people who sat in darkness have seen a great light. He convinces the people, the blacks to act now, and speak for peace in Vietnam. This is because if they do not act, they will surely be dragged down the long, dark and shameful corridors of time reserved for those who possess power without compassion...' he says they have to act because at a certain moment a man has to decide and that is 'twixt that darkness and that light' but with the surety that 'behind the din unknown standeth God within the shadow, keeping watch above his own.'

In Where Do We Go From Here, he describes negroes as still harried by day and haunted by night', then years ago' but they realized that a man cannot ride your back unless it is bent, so they made a nation rise from 'lethargy and subpoenaed its conscience to appear before the judgment seat of morality on the whole question of civil rights. That is why they need a North Star to guide them' into a future strouded with impenetrable uncertainties. 'They have to fight' until the dark yesterdays of segregated schools' be transformed to a tomorrow of quality integrated education and until 'dark yesterdays' are transformed to bright tomorrows. 
MLKJ in his speech I've been to the Mountain Top at Memphis examines his life by imaging when the age, he would have loved to live if God asked his opinion. He started from when the Israelites left Egypt, through the Roman Empire, to Martin Luther King to when Abraham Lincoln signed the Emancipation Proclamation. He continues by telling his audience he would ask the almighty to allow him to live just a few years in the second half of the twentieth century, but at the time he says the nation is sick, there is trouble in the land and confusion everywhere. 'But as he says 'I know, somehow, that only when it's dark enough, can you see the stars.' This is the moment when the blacks are asking for freedom in America and in African countries colonized by the Europeans. He goes on to say that God's children are suffering in Memphis public servants who happen to be sanitation workers are on strike. They have to march so that the world will see that God's suffering 'going hungry, going through dark and dreary nights wondering how this thing is going to come out.' He calls the day a demented woman stabbed him in New York City, dark Saturday afternoon.

MLKJ's representation of the evil of his society is vividly expressed through his use of 'dark night. He talks of dark Saturday, dungeon of shame, dark dungeon, yesterday's dark storm clouds, dungeons of oppression, who sat in darkness, dark mountain of despair, dark confused world, dark and desolate valley of segregation, long night of captivity, long night of racial injustice, starless midnight of racism, our nights become darker than a thousand midnights, starless midnight of racism, silence of the night, the darkness that seems so close around us, dark and bloody battlefields twixt that darkness, long, dark and shameful corridors, future shrouded with impenetrable uncertainties, darkness cannot put out darkness; only light can do that, dark yesterdays of segregated schools.

\section{Stench}

Stench is a very unpleasant smell that comes from something that is decomposing or emitted by the body or even the smell from a toilet. The sense of smell comes with the nose and for decay to be dictated there is an unpleasant smell around the decaying component.

\section{Electoral Fraud is Stench}

In Change Waka \&His Man Sawa boy, Mister Change Waka says 'Decaying teeth smell and we feel ashamed when we laugh in public. Yet, an ordinary chewing stick from a hibiscus hedge will help to keep your teeth clean' (pp.8). To decay is to become or make something bad by making it get rotten or decompose. A decayed tooth occurs when bacteria living in the mouth make acid and then begins to eat away the teeth and leads to toothache, gum disease and eventually tooth loss. A decayed tooth is caused by poor oral hygiene practices, improper nutrition, sugaring foods, acidic foods and drinks. So, daily brushing and flossing of the teeth, tongue and gum will reduce bad breath. This is why Mister Change Waka says ordinary chewing stick from a hibiscus hedge will help to keep the teeth clean. In Cameroon especially in Bate Besong's society, those in the villages who cannot afford toothbrushes, go for chewing stick which is a small branch from shrub or tree that is chewed at one end and used to brush the teeth. The smell from the mouth of someone with decaying teeth is hideous and no one would like sit near that one. Meanwhile the chewing stick is not bought but can be picked around. The image of smell in this instance gives a glaring description of the stench of corruption and rigging of elections in Besong's society. This, just like to be fair in elections, is not something to be brought. It is as cheap, easy and available to get as a chewing stick. The act of rigging elections is as shameful as the smell of decaying teeth.

Akonjweng describes the polling booth during Atemengeng's time to be suffering from acute indigestion. He describes this in the image 'its sewers regurgitate foul-smelling mud and waste. 
By Sesekou Atemengeng's time, it was suffering from acute indigestion...' (pp. 9). In this image the smell of indigestion of the human system and the regurgitation of the sewer are put together and used to describe the polling booths at the Ministry of elections. A sewer is an underground pipe or passage that carries sewage (waste matter from human bodies, factories) away to be treated or cleaned. Sewers are said to regurgitate and when this happens they send out a foul-smell. Also symptoms of indigestion are bloating, belching, nausea and vomiting amongst others. Bleching means expelling to the air gases from the stomach through the mouth. According to Mayo clinc(http://www.reference.com/health/causes-bleching-tastes-likesrotten-eggs-ff0407e206a60ela) belching that smells like rotten eggs are caused by hydrogen sulphide gas produced as food passes through the digestive system. The sewer regurgitating is like the stomach sending out the belch. The polling booths that produce fraudulent vote cards are like the sewers that regurgitate and the indigestion that sends out foul-smelling belches.

Atemengeng, a judge of state at the Ministry of Elections says 'the stench of decay becomes nauseating. The stench... Everyone reaches for the dust-bin to empty it on the poor thing's head. The stench... We are bound to live with corruption' (pp. 53-54). The stench here is the corruption Besong's society is bound to live with, because those in power are not ready to let power go, so there must be corruption of the polling booths for them to stay in power.

\section{Inhumanity is Stench}

Once Upon Great Lepers is a representation of a society that is engulfed in torture and oppression, and the protagonist are lepers, un-identical twins through whom the situation of post-colonial Cameroon is exposed in the kondangui concentration camp. In the opening scene the lepers are described as being 'covered with running sores and protruding acnes' (pp.11). Samndeng tells his twin brother,

'It will burst open,

spilling reddish and smelly pus.

The cancerous balloon should

discharge all its decayed contents...' (16).

The reddish and smelly pus that come out from a cancerous ballon is decay and since any decayed thing smells the contents will obviously smell. This smell represents the torture the prisoners go through in the concentration camp.

Samndeng says

When you see lepers

Talking to themselves

In the market where cadavers

Ooze noxious odor...

In the $20^{\text {th }}$ May noose...

Re-Unification water... (21)

May 20 $0^{\text {th }}$ in Cameroon is celebrated as the National Day because on May $20^{\text {th }} 1972$ there was a referendum that changed the Federal republic of Cameroon to Republic of Cameroon. Cameroon was one before the coming of the Germans. After the defeat of Germany by Bratain and France, Cameroon was divided into two. Southern Cameroons and French Cameroon which reunified in October 1961 as West Cameroon and East Cameroon respectively, foming a federal union. On the $20^{\text {th }}$ of May 1972, this federal union became United Republic of Cameroon after a referendum. The union according to West Cameroonian (Anglophones) has not been favourable because they feel marginalised by the Francophone-led government. Today Anglophones are clamouring for a federal system of government, and some are even asking for 
separation. Today in Cameroon $20^{\text {th }}$ May is celebrated as a national day, but looked upon by Anglophones as a day of enslavement. According to Besong therefore $20^{\text {th }}$ May is cadavers that ooze noxious odor.

Samndeng and Ntufam both say

...oozing out noxious matter

Called National Integration (23)

National Integration is a term used in Cameroon to dissociate those who consider Anglophones and Francophone as two different peoples. They claim Cameroon is united and one and indivisible. May $20^{\text {th }}$, reunification, National Integration are terms used in Cameroon but which Anglophones do not like because they consider these terms synonyms to marginalisation by the Francophone- led government. Today, the Anglophones are on strike because of what they term marginalisation of the Anglophones (North West and South West Region of Cameroon). Since October 11, 2016 lawyers in these regions have been on a sit-in strike and schools have not operated since November 212016 till today 14 February 2017, for the same reasons.

Samndeng goes on to say

You write urination and rude

words on the wall regarding re-

unification (in a sinister tone). We

are sending you the May $20^{\text {th }}$

alabaster with the ashes (a pause).

Rather than you have your teeth

extracted, you prefer carrying a

mouth full of rotten teeth. It is no

exaggeration to say that bad

breadth harms in any careers. (27)

A mouth with rotten teeth will obviously feel pains and will exude bad breadth. This image of bad breath is an allusion to the pain and marginalisation Anglophones in Cameroon are experiencing as a result of reunification of 11 October 1961 and the results of 20 May 1972. According to Besong therefore, the extraction of the decaying teeth is better for the Francophone-led government. The decayed teeth are the wrongs done to Anglophones that make them to always complain, even when they are being imprisoned. If the Anglophones are given their demands it will be like extracting decay tooth, and the smell of rotten teeth will stop.

Another instance of smell is when Samndeng says,

You are drugged and dragged

from the Foumban hole by the

hair. Is C.F a ticket to a happy

life? May a leper inquire why a certain body

should not end up like any other

decomposing cadaver on Re-Unification roadside? (28).

Foumban, referred to by Samndeng in the extract is where the conference held and the decision of reunification of the West and East Cameroon was taken. The decision at Foumban therefore is a decomposing cadaver that is obviously oozing out a terrible smell, and it is that of 'Re-Unification.' 
They go on to use

\author{
Etogobi people \\ suffer the most from carcase \\ pollutants (29).
}

The air is pungent with the smell

of gun powder: fiendish screams (32).

... now like an albino whale

Full of stinking muddy algae (37).

It is no exaggeration to

say that his bad breath is the

Talisman of his jean focart zeal (69).

All this gives an image of a society that is filled with inhuman treatment that makes that society to be considered a decayed one. Once Upon Great Lepers brings out social ills from the point of view of the prisoners in kondangui maximum prison. According to Besong, Samndeng and Ntufam are lepers suffering in prison because of marginalisation.

\title{
Embezzlement (and Marginalisation) is Stench
}

Beasts of No Nation is a play about the social ills in Ednuoay (spelt from the end, the word will read, Yaoundé), representing Cameroon. This city's budget is $500 \mathrm{mFCFA}$ but $450 \mathrm{mFCFA}$ is used for shit related issues like disinfectants and toilet tissues because those in authority 'eat money the way locusts eat tonnes of green (Besong 2003, pp. 102). That is, they embezzle a lot. The play is brought to view through the oppressed Night-soil men, Cripple and Blindman on one side and Narrator and Otshama as foremen for the Night-soil men and Aadingingin on the side of the oppressors. Narrator supports the oppressed while Otshama is for the oppressors. In this play Bate Besong's sense of smell portrays the ills of the society with embezzlement as a major theme. The major actors are the Night-soil men who are the oppressed Anglos (Anglophones), who cart away the excrement of the big Directors. The image of the lavatory stands out clearly, since the Night-soil men carry buckets of shit each night. These Night-soil men are not paid regularly and they are not protected from infectious diseases that come from excrement. The play opens with Besong's use of smell to prepare the audience for stench that runs through the play

The stench from the lavatory

stands in the theatre like the

pangs of SAP (Structural

Adjustment Programme) (85).

The Structural Adjustment Programme (S.A.P.) was a programme that did not actually succeed and so it is compared to the stench of the toilets from which the Night soil men cart away shit. To restructure the finances of the Cameroon S.A.P. brought instead poverty on the masses that affected the population of Cameroon negatively. In the text S.A.P. is represented negatively in different instances. Narrator says 'Let me put it to you that S.A.P. has already bitten you, and you have no future' (93) and later on he says 'When S.A.P. will sap slave-anglo' (105). Narrator represents S.A.P. as some frightful thing when he says 'S.A.P. has a lean dark face' (127) and 'like gung-ho undertakers come to collect the national corpse after S.A.P.' (133). S.A.P. therefore has the image of a dreaded beast that is gnawing the society of it vitals. The generally 
negative representation of S.A.P. go to buttress the comparison of S.A.P. to the stench from the lavatory.

The second Night- soil man says 'the lavatory is smelling' Narrator tells him 'Maybe it is your mouth that is smelling' (88). Later on the First Night-soil man complains again 'The lavatory is smelling' and the Second Night-soil man tells him to 'Fight the stench of the lavatory your own way' (102). The lavatory here represents the ills of the society. A society in which the masses do not have freedom because the First Night-soil man cries out 'give us freedom!' Since Narrator has been trying to educate the masses on their situation so they can fight back, but they will not listen, he tells them to fight the stench their own way.

The play is filled with shit and shit related issues. The big directors have big stomachs that are filled with shit. Ninth tenth of the budget is used for shit related issues. The play is all about the maltreatment of Night-soil men because the money is embezzled.The Night-soil men carry shit and are not protected. Narrator in educating them portrays their situation to the audience.

Narrator

0 you camwooed by the drunken

Gluttony of shitologicians... (123)

The image of Night-soil men camwooed with shit means they smell. Even though the Night-soil men physically smell, the stench is on the embezzlement of the gluttony of shitologicians.

\section{CONCLUSION}

Writers of texts make use of the different senses to represent their ideas through the images they use. The images of sight and smell used by the authors in the texts examined in this study are explicit in presenting the different situations as experienced by the authors. The basic assumption of Dual Coding Theory therefore is that all mental representations retain some of the concrete qualities of the external experiences from which they derive. Martin Luther King Junior represents racial discrimination through the use of darkness, a sense of sight. Bate Besong looks at the different ills of the society and represents it as decadence. According to the Conceptual Metaphor therefore, racial discrimination is darkness, and any social ill like electoral fraud, inhumanity and embezzlement (and marginalisation) is stench.

\section{References}

Alimi M M \& Ebewo, P. J. (2008). English language and Literature: Cross Cultural Currents. Newcastle:Cambridge Scholars Publishing

Ambe, H.N. (2004). Shit and Stench as Dramatic Strategy: Bate Besong's Beasts of No Nation. In Literary Criterion, C.N.Srinath et al.eds. Vol. xxxix, 3\&4, Pp 185-197.

Besong, B. (2001). Change Waka \& His Man Sawa Boy. Yaounde: Editions CLE

Besong, B. (2003).Three Plays. Yaounde: Editions CLE

Cameron, L. \& Maslen, R. ( 2010) Metaphor Analysis: Research Practice in Applied Linguistics, Social Sciences and the Humanities. London: Equinox Publishing Ltd. Dual Coding and Common Coding Theories of memory https://plato.standford.edu/enteries/mental-imagery/theories-memory.html

Goatly,A.(2010). Explorations in Stylistics. London: Equinox (www.equinoxpub.com)

Howard, M. Analyzing and interpreting Literature Study.com/academy/lesson/symbolism-imagery-literarturedefinitions-examples.html

James M. \& Paivio,M. (1991). Dual Coding Theory and Education. Educational Psychology Review Vol.3, No.3, 1991

Martin Luther King Junior (1957) Give us the Ballot

Kingencyclopedia.stanford.edu/.../doc_give_us_the_ballot_address_the_prayer_pilgrimge_for_freedom/ 
(1963) The Great March on Detroit

(1963). I Have a Dream'www.americanrhetoric.com/speeches/milkihaveadream.htm

(1964) Nobel Peace Prize Acceptance www.nobelprize.org/nobel-prizes/peace/laureates/1964/kinglecture.html.

(1967) Beyond Vietnam: A Time to Break Silence

(1967). Where Do We Go From Here. Kingencyclopedia.stanford.edu/.../where_do_we_go_from_here

(1968). I've been to the Mountain Top

www.americanrhetoric.com/speeches/mlkivebeentothemountaintop.htm

Keleshian, M. (2014). Writing Tips: The Importance of Imagery www.germmagazine.com/writing-tips-theimportance-of-imagery-by-mary-keleshian.

Lakoff, G \& Johnson, M. (1980) Conceptual Metaphor in Everyday Language The Journal of Philosophy, Vol 77, Issues 8. Pp453-486

Literary Devices http://Literarydevices.net/metaphor/

Literary Devices http://Literarydevices.net/imagery/

Nchia, E.Y. (2016). "New people, New Style, Old Dance”: An Analysis of the Dominant Ideologies in Bate Besong's Plays. Asian Journal of Humanity, Arts and Literature. Vol.3(1), Pp. 81-90.

DOI:10.18034www.biblegateway.com/resources/dictionary-of-bible-themes/4811=darkness-aas-symbol-sin

Wilkins, M.J. www.biblestudytools.com/dictionary/darkness/

Yimbu, E.N. (2016). Oral Aesthetics and the Power of Symbols in the Plays of Derek Walcott and Bate Besong. Path of Science, Vol 2(10). Pp 2.28-2.40. DOI:10.22178. 